\title{
Unreasonable Resentments
}

\author{
Alice MacLachlan
}

\section{Introduction: The Claims of Resentment}

How ought we to evaluate and respond to expressions of anger and resentment? Can philosophical analysis of resentment as the emotional expression of a moral claim help us to distinguish which resentments ought to be taken seriously? Philosophical work on responsibility and wrongdoing has shifted from a singular focus on determinations of culpability, retribution and compensation to include the social meanings, identities and relationships that emerge in the aftermath of harm, and how these relationships and identities might need some kind of repair and recognition. With this new focus comes renewed interest in the affective dimensions of wrongful harm, and their implications for our social and political relationships. In other words, we are learning not just to take wrongs seriously, but to take claims of wrong seriously: who makes them, to whom they are addressed, and how they are made; their performance and ritual, their context, and their affective emotional inflection; and the implications of these, too, for our social and political relationships. Responsible social and political agents must, it seems, concern themselves with the symbolic and affective meanings of these claims beyond their identifiable objective content. And this concern means reflecting on the emotions acts of wrongdoing raise in us, as well as our practices for expressing and responding to these emotions.

Victims and bystanders experience a number of emotions in the aftermath of conflict: grief, sorrow, rage, shock, horror, sympathy, hopelessness-as well as hope, guilt, and resolve. Yet anger and its variations are often singled out as being specific and somehow especially appropriate responses to wrongdoing. Indeed, with new attention to the affective dimensions of wrongdoing, philosophers have revalued a rather notorious reactive attitude_-resentment_-demonstrating how it can be good and even virtuous, both an emotional "commitment to certain moral standards" and, simultaneously, a testimony to that commitment (Wallace 1994, 69). In resenting, they argue, we necessarily make claims about the good, as well as our own standing as a moral agent, deserving of respect. Indeed, if such claims are a necessary condition of practices of resentment, then these emotional practices are also moral.

In emphasizing the moral function of resentment as one kind of anger, one could argue philosophers have offered an important service to angry victims of political violence, who are often voiceless except in their ability to articulate and

JOURNAL of SOCIAL PHILOSOPHY, Vol. 41 No. 4, Winter 2010, 422-441.

(C) 2010 Wiley Periodicals, Inc. 
express resentment. ${ }^{1}$ This argument is not mistaken, but neither does it tell the entire story. Philosophers have salvaged resentment, connecting it to evident, recognizable moral values: our sense of justice, our practice of holding others accountable, and our self-respect. In part, they have done so by isolating and identifying a subset of possible "angry" reactions: those that can be identified (or reconstructed) as making a recognizable moral claim. The unspoken implication is that not all angers are worth taking seriously, but some recognizable sub-genres of anger are. In focusing on just those resentments that are easily salvaged, philosophers have presented a paradigm of reasonable, even "moralized" resentment. "Resentment" is anger that is at least potentially deserving of our moral attention. Other angers can be taken seriously, insofar as they resemble this paradigm; it thus represents a limit on their uptake as morally significant. Yet, these rarified forms of anger may not be available to those who have the most to resent, suggesting that if one motivation for a philosophical account of anger is giving voice to victims, a broad rather than narrow account of anger may be appropriate.

After all, where does the philosophical story leave unreasonable resentments: those angry reactions that plausibly share an emotional phenomenology with the philosophical paradigm of reasonable resentment, but cannot meet its criteria, that is, cannot be reconstructed as an intelligible, recognizably moral claim? It is not my intention to argue that all angers are reasonable, or that there is nothing to be gained in identifying those that are, but an exclusive focus on what distinguishes "reasonable" resentment from other, "unreasonable" angers may overshadow the morally and politically valuable roles that quintessentially unreasonable angers (at least from our current perspective) can play.

In the following paper, I defend three claims about the ethics and politics of resentment. First, I claim that the account philosophers offer of resentment-its distinctive features, aims, rationality, and gratification-will affect the conclusions we draw about which actual resentments to take seriously, which aspects of resentful claims need addressing, and what it means to address and repair them. In contesting definitions of resentment, therefore, we do more than simply perform housekeeping in philosophical taxonomies of emotion. Second, I suggest that the range of angers we have a prima facie reason to take seriously is broader than philosophical discussions of anger have so far allowed, and in ways that the standard approach cannot incorporate, even when tweaked. Finally, I note that restricting our understanding to essentially "moral" cases may cause us to lose sight of expressly political resentments, and that this oversight has ethical as well as political consequences. Our resentments can express political as well as moral claims, and furthermore, both types of claims - when viewed in a broader socialpolitical context - may take on ethical, as well as political, significance for the observer (if, e.g., they signal broader social injustice). Put simply, philosophical accounts of resentment have both overmoralized and undermoralized resentment: they have overmoralized the content of resentment and, as a result, risked overlooking or covering over the ethical significance of resentments without overtly moral content. 
The argument proceeds in two stages. First, I consider the standard philosophical account of resentment, representing the vast majority of contemporary discussion on the topic. Almost without exception, philosophers, political theorists, sociologists, and psychologists have taken this account of resentment to be the authoritative philosophical word on the subject. This philosophical paradigm is not coextensive with ordinary language use of "resentment" or with Nietzschean accounts of ressentiment, but it inherits a great deal from discussions of resentment found in the work of eighteenth century philosophers Joseph Butler and Adam Smith. The "reasonable" account is attractive in part because it mitigates resentment's reputation as self-perpetuating, deceitful, and antisocial.

Second, I turn to "unreasonable" resentment, considering which recognizable resentments cannot be represented in the terms of current philosophical debate - or which, if they can, appear distorted by that representation. My analysis of "unreasonable" resentment has two significant implications: first, there are three small but significant adjustments that should be made to the "reasonable" account for it to successfully play the role that philosophers would like it to do. A plausible account of resentment must acknowledge that we resent violations and threats that (1) are not necessarily self-pertaining; (2) may not be expressible as individual, discrete injuries; and (3) cannot always be construed as moral threats in the sense of rights violations. My second conclusion is more radical: given the dependence of individual moral judgments on a broader horizon of moral possibility, philosophical standards of "reasonable" or "appropriate" resentment cannot avoid being politically charged. Thus, the widely accepted account of "reasonable" resentment cannot make philosophical sense of some of the most interesting and perplexing cases. Ironically, a theoretical measure designed to revalue emotional expressions of moral protest may result in the exclusion and silencing of those with the most serious wrongs to protest.

\section{What is Resentment? The Standard Philosophical Story}

I am concerned with resentment as an emotion or emotional attitude, not a disposition (someone who is easily inclined to the emotion of resentment) or a state of character (someone who is always or often resentful). Of course, what exactly emotions are remains a subject of dispute within and beyond philosophical literature. In referring to resentment as an emotion, I understand it to be a complex adaptive response to certain situational factors, often socially experienced and understood, an episode of which may or may not include physiological changes, ways of feeling, motivations and dispositions to act in certain ways andimportantly — particular thoughts, perceptions, and evaluations of this situation. In other words, emotional experiences like resentment include but are not reducible to evaluative construal of the agent's environment that is open to rational assessment. I have already described resentment as a retributive emotion. It is, among other things, a kind of anger (although resentment may be inflected by fear, envy, and other emotions). 
This is not a very controversial claim: Margaret Urban Walker notes everyone who writes on resentment agrees it is a kind of anger (Walker 2006, 110). ${ }^{2}$ The everyday language of emotion terms is intricate and variable: most of us have roughly defined and shifting clusters of intuitions about the finer distinctions and connections between resentment, and-for example-indignation, irritation, frustration, outrage, begrudgement, distress, contempt, hatred, malice, schadenfreude, vengefulness, vindication, and rage. It is thus understandable that most philosophers writing on the topic have chosen to treat resentment as a technical term: resentment is a kind of anger, they argue, but not all anger is resentment. ${ }^{3}$ Instead, resentment is a "cognitive sharpening" of anger, identified by certain constitutive thoughts (D'Arms and Jacobson 1993, 143). As Thomas Brudholm puts it: "resentment . . . is distinguished not by how it feels, but by the way in which those who account for it make reference to perceived injustice, injury or violation" (Brudholm 2008, 11). Resentment is anger that arises in response to a certain kind of threat: that is, an unjustified, intentional injury, harm, or insult to oneself, or those with whom one identifies closely. Indeed, because of its cognitive structure, resentment also qualifies as a moral attitude — not because it is necessarily righteous or justified, but because its explanation is always morally laden. As John Rawls puts it, resentment is a "moral feeling that invokes the concept of right" (Rawls 1987, 533). A purely amoral or self-interested person could not experience resentment, Rawls argues; she could only feel anger or annoyance at slights and harms, or envy at others' desired resources or circumstances (Rawls 1987, 487). ${ }^{4}$

So, we understandably resent violations of our rights: that is, wrongful injuries to ourselves, or those with whom we so closely identify that we see them as ourselves: the standard example offered of the latter is a mother resenting on behalf of her child. In resenting, Jeffrie Murphy claims, the victim experiences and expresses a kind of three-pronged moral protest: she protests the injury as an attack on (1) the Kantian value of respect for persons; (2) her own value as just such a person; and (3) respect for moral values in general. ${ }^{5}$ As a result, he concludes, resentment is good, and may even be a virtue-if for no other reason than because it is clearly and unproblematically tied to "a non-controversially good thing-self-respect" (Murphy and Hampton 1988, 16). When we fail to resent appropriately, we convey "emotionally-either that we do not think that we have rights or that we do not take our rights very seriously" (Murphy and Hampton 1988, 17). Jean Hampton's view of resentment, expressed in conversation with Murphy, is less unqualifiedly praising: she worries that resentment is selfundermining, precisely for the ways in which it is bound up in our sense of our own dignity and moral worth (Murphy and Hampton 1988, 57). Both Hampton and Murphy cast resentment as an "emotional testimony" to our moral values, in particular Murphy $(2003,19)$. Others who discuss resentment have tended to accept some variation of Murphy or Hampton's account. ${ }^{6}$

This technical account of resentment treats it as the first-personal analogue of moral indignation: the emotional equivalent of blame or moral disapproval toward discrete, wrongful injuries to the resenter. Such resentments can still go wrong, 
philosophers acknowledge, just as our subjective appraisals of blame and demerit do: we can misconstrue the situation or target the wrong person as the cause of our injury, and we can also blame disproportionately-exaggerating the offense, or ignoring excusing conditions. As an emotional state with attendant desires and motivations, resentment can go wrong in other ways, too: even justified resentment can lead to excessive and violent acts of retribution. It can preoccupy the bearer to the neglect of other serious moral considerations and-over time-a fierce and nagging resentment causes harm to the person who experiences it (Murphy and Hampton 1988, 57). Certainly, a constant state of anger is not conducive to personal flourishing, however much one's circumstances warrant it (Tessman 2005, 90).

Despite its associated risks, the claim that distinguishes "reasonable" resentment is a legitimate moral claim, requiring some form of contrary or discrediting evidence to be overturned: the resenter, in resenting, identifies inappropriate treatment according to certain universalizable standards, she protests the injury, and she seeks condemnation of the wrong-either from the perpetrator (in the form of apology or reparations) or from others, through acknowledgment, group disapproval, and mechanisms of justice (Murphy and Hampton 1988). Resentment may not always be a pleasant emotion for the resenter, for her target or for others nearby, but it is certainly not an intrinsically bad emotion, and under the right conditions, it is certainly reasonable.

In other words, the standard philosophical paradigm of resentment is "reasonable" not in the sense of being necessarily moderate or appropriate-as a virtue account might argue, for example-but in the sense of being rational or moral: it necessarily refers to a moral infraction or violation of some kind. There are a number of cases of resentment that fit the above picture very well. If you hit me or you deeply insult me, I will probably (among other reactions) resent you. I may come to resent you both for the attack or the insult, and the message both carry about my worth and my value to you. My resentment functions as an emotional riposte; in resenting, I reject your message of disvalue and communicate the wrongness of your act.

The motivation behind a moralized account of resentment is also understandable, and indeed, admirable, especially if we see such an account as the effort to rehabilitate a supposedly "negative" and somewhat notorious emotion-to distinguish it from bitterness on the one hand, and envy on the other. ${ }^{7}$ Resentment's current bad reputation owes much to its association with Nietzsche's description of ressentiment (perhaps best described as existential resentment) as "an angry spectator of all things past," whose frustration is creative, scheming, hateful, dishonest, corrupting, poisonous, and ultimately self-undermining. Part of the distaste of ressentiment is, for Nietzsche and others, its constant effort to disguise itself as something meritorious. While Nietzsche condemns much of our moral framework along with resentment, his account of the emotion itself is compelling. He captures what Charles Griswold refers to as "resentment's famous propensity to tell a justificatory story about itself” (Griswold 2007, xix), a propensity that 
might make us distrustful of the justifications it ends up providing: resentment is the sort of anger that tells convincing stories about itself. A good way to rehabilitate resentment, then, is to focus on just those resentments whose justificatory stories have strong, easily identifiable moral claims behind them. Other resentments can then be taken seriously, insofar as they resemble these, that is, insofar as they express a rational response to moral infraction.

This approach mitigates the admittedly unpleasant phenomenology of resentment. ${ }^{8}$ Resentment is often disagreeable, and not just to its object. As Adam Smith says, resentment is "harsh, jarring, and convulsive, something that tears and distracts the breast, and is altogether destructive of that composure and tranquility of mind which is so necessary to happiness" (Smith 1976, 37). Smith also remarks that resentment is the emotion with which others are least able to sympathize: "it was, it seems, the intention of Nature, that those rougher and more unamiable emotions ... should be less easily and more rarely communicated" (Smith 1976, 37). Audre Lorde notes that our fear of anger and resentment deflects us from having necessary, difficult conversations; "it is very difficult to stand still and to listen to another woman's voice delineate an agony I do not share, or one to which I myself have contributed" (Lorde 1984, 128). Between resentment's bad reputation and its experiential discomfort, it can be easy to let it slip into the wrong side of a too-easy dichotomy between "good" reconciliation and peacemaking, and "bad" anger and aggression. Resentment can be alienating.

Murphy and others rescue resentment from discomfort and alienation by "cleaning it up" and by connecting it directly to recognizably moral values: namely our sense of justice, our practices of holding others accountable and protesting wrongdoing, and our self-respect. ${ }^{9}$ In emphasizing the moralizing function of resentment, these philosophers offer an important service to angry victims of political violence, for example, who may otherwise get swept up in the push to reconcile, to end conflict, restore normal relations, and resume business as usual.

Nevertheless, it seems to be very important to ask what is left behind, in the wake of this philosophical rescue mission. Philosophers like Murphy present a useful paradigm for explaining how we respond emotionally to what we take to be explicit and identifiable moral injuries we have suffered. They enable us to tell a story about resentment as a moral sentiment, and the disposition to resent in a range of appropriate conditions as a plausible moral virtue. ${ }^{10}$ Such an account is potentially useful for a wide range of philosophical issues: from retributivist theories of punishment (Bennett 2002) to meta-ethical debates over sentimentalism (D'Arms and Jacobson 1993), where the fact of wrongdoing is not in question, but only the nature of that wrongdoing (and the wrongdoer's corresponding desert) is. But does it tell us everything we need to know about resentment, for the purposes of theorizing about wrongdoing?

My critique of the standard account is twofold. First, the account is descriptively inadequate. It fails to make sense of instances of anger that are plausibly characterized as resentment: on phenomenological lines, according to our everyday uses of the word, and even according to the standards of the philosophical 
account itself. Paying attention to these inadequacies reveals ways in which the account ought to be tweaked to best achieve its own, self-proclaimed function (namely, best identifying those instances of anger that are recognizable moral claims). However, incorporating apparent counter examples is not only a matter of improving a particular philosophical taxonomy (or indeed, substituting the intuitions of other philosophers for my own). My second critical claim is that dividing angers as either "reasonable" or "unreasonable" will tend, almost inevitably, to dismiss the angers of the most vulnerable: those least likely to have their needs and interests represented in a dominant social and moral framework.

\section{The Descriptive Inadequacy of "Reasonable" Resentment}

Moral injuries are not the only things we resent, at least according to most non-philosophical understandings of the word. I resent individual acts of moral injury, yes, but I might also come to resent other kinds of threats and burdens to my well-being: a difficult and unrewarding job, for example, especially if I feel trapped or locked into it. I can come to resent the contours of a draining, demanding relationship or an onerous care-giving one-on the other hand, I may resent needing and receiving care, and the vulnerability that entails. I may resent you for failing to live up to my expectations, for letting me down, or for your poor treatment of someone else, especially if your behavior reflects on me. Griswold gives the example of a persistent, painful disease; over time, my reaction to it might at least "feel" like resentment (Griswold 2007, 22). People resent changes to their homes and neighborhoods, or to places with a sense of history or the beauty of nature. They resent failures of good manners, of reciprocal social conventions, of "respectability" and "decency," and even of fashion. Some people resent taxi drivers with foreign accents that are hard to understand, critical analysis of well-loved cultural icons (and conversely, lack of minority representation in the same), efforts to make accessible and inclusive spaces, individuals who do not dress according to class, cultural, or gender norms, and even-as Alan Gibbard notes_-peculiar haircuts (Walker 2006, 124). ${ }^{11}$

But why should philosophers interested in resentment qua moral sentiment or virtuous attitude care that ordinary language use of the term is much messier, and may conflate resentment with non-moral angers, with envy and with begrudgement? In the first place, non-paradigmatic examples of resentment draw attention to three descriptive limitations of the philosophical account: ${ }^{12}$ namely that, according to this account (1) resentment is necessarily self-pertaining; that (2) it concerns itself only with violations of my moral rights; and that (3) it responds to discrete occasions of injury. There are plausible counter examples to each of these stipulations. Because of these, the philosophical account fails on its own terms: it cannot locate all and only those resentments that meet its standard for recognizable, legitimate claims.

Once we taken into account the importance of caring relationships, our imaginative and emotional engagement with other people, and our relational and 
group identifications, it becomes obvious that the injuries we resent are not always our own, but rather, those we take personally: these can include injuries to those to whom we are partial or for whom we care significantly, or with whom we share thick group identifications. We may also resent violations of other, less obviously moral, norms and standards with which we identify: my sense of "good" philosophical teaching, my commitment to the etiquette of public transit, or my fervent belief that white ought not to be worn after Labor Day, for example. Many people find themselves resenting other's failures and betrayals, carelessness and manipulation even when these do not violate the resenter's moral rights. We may also resent others' failures to live up to the good or to our expectations of the good, when such failures affect us personally. Yet it is not always clear we are injured by such disappointments. Resentment is better described as "ethical"- that is, concerned with evaluative construal more generally - than "moral," if by moral we understand the domain of rights and duties, specifically. ${ }^{13}$

Murphy ties resentment to our expectations of justice: that is, our sense of moral norms. And he is right to focus both on norms (things of value) and our expectations: the ways in which certain norms govern and predict our comfortable experience of the world. But moral norms are not the only values to play this organizing role. We have social expectations about our inclusion in certain groups and communities. ${ }^{14}$ We also have certain expectations of stability and security, of normalcy and the everyday. These are often connected with morally significant norms (the rights and obligations of democratic citizenship, expectations of cultural rights, and so on) but they are not always identical_or even reducible - to them. Disruptions to any one of these expectations can lead to emotional experiences of resentment. Furthermore, as Gibbard's glib references to haircuts suggests, we are governed by explicitly non-moral norms of social etiquette, custom, and fashion: these may range from the morally compelling to the morally neutral or even repulsive. There is a danger in collapsing all norms to moral norms, both for the integrity of the moral and the integrity of the political or social. In a rich life, other kinds of value will have a hold on us and will govern the expectations we have of our surrounding environment.

Third, not all occasions for resentment are "injuries," in the sense of being discrete, individual events. Someone may resent a set of unjust circumstances or the culmination of many events over time. Feminist theorists have demonstrated how violence against women should not be seen as individual occasions of brute wrongdoing, but must be placed in context of a patriarchal society that does not value women; this is the message that rape and other violence conveys, and it is a message directed at more people than the individual woman or women harmed. To resent those wrongs is to reject and to protest that broader message as well as the individual infraction-and here, if "resentment" appears too weak a term to convey the appropriate reactions, recall Brudholm's point that resentment is a matter of why I am angry, and not a measure of the extent of my anger. For this reason, feminists have rightly drawn attention to the moral and political value of women's anger. Furthermore, when Audre Lorde says “anger is an appropriate 
reaction to racist attitudes, as is fury when the actions arising from those attitudes do not change" (Lorde 1984, 129), the anger she speaks of is resentment.

Opening up the possibility of group resentments makes it harder to distinguish between reasonable and unreasonable cases. For example, in the wake of the Canadian government apology to survivors of Indian Residential Schools and the Indian Residential Schools Truth and Reconciliation Commission, nonindigenous Canadians have been forced to face the resentment of First Nations peoples, often for the first time, leading to a complicated dialectic of exchanged resentments. ${ }^{15}$ Indigenous claims are directed at non-indigenous Canadians, and part of their resentment comes from the non-indigenous Canadians' refusal to recognize grounds for resentment:

There is a brooding resentment for a life that is damaged. There is anger for a childhood that is lost. There is profound emptiness and a sadness that comes from the loss of an opportunity to be raised in a nurturing family environment. . . Michelline Ammaq is left with a great yearning to know a life that has never been lived. These feelings are the unfortunate legacies, the bitter byproducts, of a residential school experience. These feelings are shared by many who passed through Canada's 'Indian' residential school system. (Kilpatrick 2006)

In return, non-indigenous Canadians appear to resent even hearing stories that alter founding myths and understandings of Canada as a gentle, peacemaking nation:

\begin{abstract}
Non-aboriginal natives of Canada like myself are doomed to forever shoulder the counterfeit guilt and financial burden of a culture of victimhood ... exaggerated and perpetuated for all eternity as a convenient blame for every weakness and reluctance by some people and groups not to join the world and get on with their lives. (Smiley 2008)

He stated the crimes of the white man would be born by all white men. This time it was my turn to take offense! What had my family ever done to him or his people?! Why do I need to pay for crimes nobody in my family ever committed? BTW, if anybody was being racist in this exchange, it would appear that he was promoting hatred along ethnic lines not me. For some reason I still do not understand, this conversation ended on a very sour note as he exited the room with nary a word of farewell. (Getz 2008)
\end{abstract}

At least part of the resistance expressed by non-indigenous Canadians, here, stems from an inability to comprehend how they can be held responsible for-or at least implicated by-something as large and sprawling as the destruction of whole lives, even generations of broken communities. They resent being placed against a context of history over which they have little control. As Smith so aptly explained, resentment is "harsh, jarring" and alienating: listening to another's expression of resentment can make us uncomfortable, even angry. We resent being forced to listen to others' claims, and the ways in which those claims might transform our reality, or command us to change. Resentment can express the sentiment, "just who do you think you are?" as easily as it does, "this isn't fair." 
In situations like these, disentangling and identifying discrete reasons and targets for anger is a formidable task, and there remains a further question of whether we can be certain that the resultant itemized list of individual resentment claims represents - and does not distort - either the phenomenology or the object of the original angers. Once our capacity to identify not only with other members of a particular group but also with particular norms, standards, and institutions is recognized, the range of resentments we may experience is multiplied exponentially, along with our various identifications. As feminist explorations of identity, intersectionality and oppression have demonstrated, the wrongs associated with racial, class, and gender oppression may not simply add on to one another (Crenshaw 1989). A single resentful reaction may express a multitude of fears, jealousies, and angers, some of which-in isolated form-are more justifiable than others. Yet, presumably, responding appropriately to such complex resentment does not always entail weighing the good against the bad and making a single overall judgment: the "brooding resentment" described in the Kilpatrick quotation suggests these complaints are not always separable. Thus, the account provided by Murphy et al. leaves us with insufficient resources to perform necessary but more subtle analyses.

The first and second concerns, when taken together, do not manifest an insurmountable problem for the philosophical account of "reasonable" resentment: indeed, it can be tweaked to incorporate them, just so long as "injury" is defined broadly enough. The third concern is the most difficult: in lives marked by injury and injustice, resentments may pile on one another in an indistinguishable fashion, ultimately masking one another. But all three taken together perhaps suggest something more worrying: the descriptive inadequacy of the standard account not only overlooks socially and politically motivated resentments, but it does so at the cost of those whose social and political resentments are most likely to arise from social vulnerability and experiences of injustice.

\section{The Political Dangers of "Reasonable" Resentment}

Must a proponent of the standard philosophical account of resentment accept the accusation of descriptive inadequacy? Should she wish to resist it, she has a couple of strategies at her disposal. The first is simply to acknowledge my counter examples as nothing more than symptoms of messy ordinary language and everyday, non-philosophical thinking. Yes, there are certain similarities between these kinds of grudges, fears, and displacements, and properly moral resentment, but unless they can be captured by the moralized account-in which case further explanation is redundant - there is an equally important dis-analogy: the lack of a robust moral framework. This dis-analogy, the proponent might argue, gives us good reason to distinguish them and to accept only the latter as resentments worth rehabilitating. True, some genuine resentments may be misplaced, excessive, or recalcitrant, but my counter examples of supposed non-moral resentments are 
something else altogether: a kind of political or even existential grudge-holding, or ressentiment.

Griswold adopts this approach, recognizing both resentment and what he calls ressentiment, borrowing Nietzsche's terminology: "including as it does malice, desire for revenge, envy ... but also anxiety, suspicion, the holding of a grudge, a hatred of whatever or whoever one feels has called one's standing into question, a feeling of powerlessness, a loss of self-respect, and . . . a generalized sense that the world is unfair. It suggests frustrated and repressed anger" (Griswold 2007, xx). ${ }^{16}$ Resentment is reasonable, while ressentiment, for Griswold, verges on the pathological.

Such a strategy is mistaken - not least because to call every instance of resentment that falls short of evident moral injury an example of ressentiment seems to prejudice us against their potential value, given ressentiment's historical notoriety and negative valuation. But even without that particular title, the strategy is worrying. After all, malice, vengefulness, and hatred of all challenges to one's status are fairly vicious orientations to the world. Why lump them together with a feeling of powerlessness, frustration, or even a generalized sense that the world is unfair, as belonging beyond the limits of reasonable resentment? Sometimes, for some people, the world really is unfair, even if not every aspect of its unfairness can be traced to discrete instances of culpable wrongdoing on the part of individual moral agents: we see where to place responsibility for its apparent unfairness only when we broaden our understanding of appropriate objects of resentment. In developing a paradigm for what counts as resentment, philosophers are also placing limits on what emotions receive uptake as resentment: a not insignificant limit, once we recognize how many wrongs take place in broader contexts of political inequality and oppression.

In other words, this strategy does not address a deeper concern: in conferring a certain status on some angers and not others, the philosophical account amounts to granting certain angers respect as "moral messengers" of sorts. Recognizing a particular episode as an episode of resentment therefore functions as at least a prima facie justification of that episode; the designation resentment, as newly revaluated by philosophers, lends authority to expressions of anger and protest. Who determines which angers are "reasonable" resentments, and who benefits from these determinations? Longstanding situations of social and political injustice are maintained precisely because often, well-meaning members of dominant and oppressive social groups lack (or consciously deny themselves) the imaginative and conceptual resources to recognize injustice as such. Many instances of resentment directed toward long-term, systemic, and collectively sustained injustice will most likely fall outside recognizable "reasonable" boundaries. Given how many expressions of anger and protest occur in politically charged contexts, the choice to draw narrower limits to resentment than recognized in ordinary language thus surely requires justification.

Drawing the line at explicitly moral resentments limits the function of our emotional expressions to the articulation of already recognizable types of moral 
claims. The class of reasonable resentments is not limited to justified instances of these types of claims, of course; individual reasonable resentments can go wrong. But it does focus on those instances of resentment that can be formulated as moral types, given our current moral and conceptual resources. So, for example, I can recognize your individual resentment as an instance of type A (say, e.g., resentment at having been discriminated against on the basis of your gender), without thereby thinking your resentment in this particular case is justified (I may believe you to be mistaken in thinking you were the victim of discrimination, or I might think your resentment to be an overreaction). But even this dismissal relies on my initial willingness to evaluate it as a moral claim at all.

Yet philosophers have reclaimed the moral value of our emotions in part because of their capacity to track aspects of reality not articulable in a given conceptual framework, especially if that framework has arisen in social conditions of oppression. Carol Gilligan refers to anger as the "bellwether" of injustice; it alerts us to a problem on the horizon (vague, uncertain) before we can identify it (Gilligan 1990, 290). In Alison Jaggar's discussion of emotions, for example, she notes that within a hierarchical society, in which predominating norms and values - including moral norms and values - will tend to service the interest of the dominant group, those most burdened by the status quo may find themselves experiencing "outlaw" emotions. One example she gives is people "who feel resentment rather than gratitude for welfare payments" (Jaggar 2008, 697). Without an appropriate critique of capitalist-patriarchy, it is hard to see a moral claim in the resentment of government welfare. Robin Dillon also describes recalcitrant resentment as a bellwether - to borrow Gilligan's phrase — of a deeper problem, not currently articulable in the resenter's horizon of possibilities (Dillon 1997, 233).

Some "outlaw" emotions may not be capable of articulation as expressions of moral protest - or even externally recognizable as instances of moral protestprecisely because what is worthy of resentment is, in part, a flawed and oppressive moral framework, incapable of sustaining such a claim. Consider, for example, feminist writer Dorothy Allison's memoirs of growing up desperately poor, smart, and queer, in a family filled with violence and incest in the Southern U.S.A. Her resentment does not begin as moral protest at all, but an almost physical hold:

It was hunger I felt then, raw and terrible, a shaking deep down inside me, as if my rage had used up everything I had ever eaten . . . that dizzy desperate hunger edged with hatred and an aching lust to hurt somebody back. It was a hunger in the back of the throat, not the belly, an echoing emptiness that ached for the release of screaming. (Allison 1992, 98)

Allison's memoirs and stories illustrate how impossible it would have been for her to describe what she felt as resentment: her anger "aches" for vocalization - in the absence of available words, she will settle for "screaming." Even as an adult, Allison cannot always make sense of her anger, morally. In one essay, she recalls an invitation to speak to an earnest, clean-cut group of liberal 
Anglicans about "the lesbian experience." Despite their welcoming enthusiasm, evident politeness and respectful questions,

I stepped out into the sunshine when the meeting was over, angry at [what she only later reads as a] contemptuous attitude implied by all their questioning, though I did not know why, so deeply depressed I couldn't even cry. (Allison 1994, 31)

At another point, in discussing her early relationships, Allison remarks:

I knew damn well that no one would want to hear the truth about poverty, the hopelessness and fear, the feeling that nothing I did would ever make any difference and the raging resentment that burned beneath my jokes. (Allison 1994, 22)

Jaggar, Dillon, and Allison all describe resentment that arises in part because the source of that resentment is not currently recognizable as injustice. ${ }^{17}$ Fitting into this category are the resentments of those who remain most marginalized: illegal immigrants, detainees, those living with mental illness, or - as described above-Indian Residential Schools survivors and their descendents, whose status of victims is couched in problematic stereotypes of abuse, alcoholism, and cultural defeatism.

Let me be clear here: the point is not to argue that all instances or even types of resentments are equally justified or legitimate. They are not. The question is whether the line dividing "reasonable" resentments (both justified and unjustified) from other, similar angers (again, both justified and unjustified) is the right kind of line to draw. And given how heavily the test of "reasonable" relies on broad social recognition of a particular injustice, we have good reason to think it is not the right line.

There is a second strategy available to the proponent of "reasonable" resentment. She can argue that while other morally significant cases may not look like reasonable resentment from the outside, this is not the case from the perspective of the resenter. To the resenter herself, her cause appears appropriately like a moral injury and threat to her self-respect, however erroneous (from our perspective) that appearance might be. In other words, the central claim - that resentment presupposes the judgment that I have been morally wronged-would still stand. Only the resenter herself, however, needs to be able to articulate that judgment; resentment invokes only a subjective "concept of right," and does not require social consensus on the matter. So, society at large may not recognize the claims of the marginalized, but presumably the marginalized themselves do. This may even be true for more apparently trivial resentments: insofar as we resent a changing neighborhood, a shocking haircut or defiance of gender or social norms, we simply do-at the same time-believe that our commitments to neighborhoods, haircuts, and gender norms are, in an important sense, moral commitments. Perhaps the shocking haircut is worn to church or the neighborhood represents the first settlement of immigrant forefathers; there might even be talk of how kids 
today have no "decency," "sense of respect" for tradition or for nature. Even if the resenter does not immediately recognize her resentment as the expression of a moral claim, with sufficient reflection and interrogation by others a moral claim will emerge, be it spurious or justified.

Certainly this strategy seems more promising than the first, in that it takes seriously that a wide variety of claims can nonetheless share a similar structure or phenomenology, namely that something of value to me has been seriously threatened, and that I protest - even defy - this threat. It does not require that society recognize the resenter's claim as a moral one, but it does require that she recognize it as such, for her experience to "count" as resentment.

Nevertheless, there are two major problems with this strategy. In the first place, it seems to assume what is in question. To insist that underneath every vague sense of unfairness or grievance is a moralized claim about a right violated or an injury done stretches these words past their useful meanings. In some cases (the haircut or the bad job) it seems downright implausible; and claiming-well, if you resent it, you must see it as a moral injury of some kind-simply begs the question. We end up counting too many things as moral.

The second problem is more worrying. This strategy continues to place the burden of proof on the resenter (i.e., the putative victim). She may not need to prove the legitimacy of her claim as moral to others, but she must still go through what may be a Herculean effort to recognize it as such, herself. Assuming that individual recognition of a particular moral claim is always, or even often, achievable without some social recognition of the same claim, is a rather optimistic account of how we can make independent sense of our emotional experiences. More plausible is Sue Campbell's claim that in the absence of social uptake and acknowledgment, expressions of anger or resentment may be unrecognizable at first, even to their bearer (Campbell 1994, 54).

This is not to say that we never have any analytic access to socially unacceptable resentments. In fact, I suspect that resentment plays as great a role in moral discovery as it does in moral expression. Our resentments can help us to track what it is we value; working out which of these values are worth pursuing, and which we might take up as ethical claims must still follow. Our ability to work this out is contingent and fraught with difficulties. Gilligan's metaphor of the "bellwether" is a much better-if less strident-account of the relationship between resentful anger and moral claims than Murphy's three-pronged expression of moral protest. In other words, the second strategy gets the significance of resentments backwards; rather than deciding whether something is resentment by whether or not it presupposes a recognizable moral claim, surely we can learn something about what matters to us, and what we consider acceptable treatment, from what we do or do not resent-independently of whether our resentments can be articulated morally in the context of our moral community and its horizon of possibilities.

Thus, taking seriously the possibility of social or political resentment-and furthermore, recognizing both the political and the ethical significance of such 
social and political resentments-requires that we re-envision resentment. What we resent reveals what it is we value, and what we have come to expect (or hope) from others; it may also reveal to what we see ourselves as entitled: that is, how our expectations of our surroundings are organized and measured. Many of these expectations will be moral, but others will be political or social: they will draw on understandings of the norms that govern any number of communities and roles we inhabit.

Why lump these moral, political, and social experiences under a single term or set of related terms? The emotional phenomenology of resentment is the same in each case; our angry feelings represent a desire - a demand - that the transgressor of some norm be held accountable to that norm, that she be made to acknowledge its force, to regret her violation. To this extent, it does invoke a concept of "right" - or at least, of value, but the value in question is not always moral (Walker 2006, 127). As Marilyn Frye says, "anger is always righteous" (Frye 1983, 86), or it at least claims to be, but the "right" in question is not necessarily a moral right. It can even be a generalized or unspecific sense of propriety, justified along one of a number of social, political, aesthetic, or personal lines.

In other words, an account that sets forth "reasonable" resentment as a paradigm misses something important, by tying the phenomenology of resentment - that is, its tendency to be personal, to justify itself (by telling compelling stories), and to endure - to a particular kind of provocation: namely discrete moral injury. The kinds of justifying stories that our resentments tell may rely on a variety of senses of "justification" and may be inflected by fear, shame, defiance, and confidence in turn: each changing the note on which resentment is expressed. And the social context in which we make resentment claims, against which our demands are normalized, will also affect the extent to which our demands are capable of being moralized.

\section{Conclusions: Reasonable and Unreasonable Resentments}

I have suggested that philosophers would do well to attend to what I have called "unreasonable" resentments: expressions of anger that bear phenomenological resemblance to the instances of resentment cited by Murphy and those who follow him, but which cannot be comfortably located within the paradigm of resentment they describe. If resentments are not always identifiable as expressions of a recognizable moral claim (my protest against an injurious violation of my rights), how can we recognize them at all? The grammar of our emotional experiences and the language with which we describe them are undoubtedly messy; I am skeptical that any neat genus-species division between anger and resentment will stand up to sustained philosophical scrutiny, especially once the political implications of isolating certain anger claims are taken into account. What I have tried to focus on, instead, is the internal logic of central and less central cases of resentment: the senses in which it is personal though not necessarily selfpertaining, the ways in which it rationalizes and justifies its claims through 
appeals to what I take to be valuable and what I think I might expect. The pay-off of this approach is not only a more sensitive and accurate account of the relationships between our moral resentments and other kinds, but also a better sense of what our resentments can teach us. In reducing all resentments to moral resentments, we risk both overmoralizing and undermoralizing the work that resentment does.

Why do cases of resentment that are not obviously "moral" matter? They matter first because, outside of thought experiments, these are the cases that philosophers will find themselves examining: resentments that have piled up indistinguishably, resentments based on group identification and long-term historical claims, resentments directed at the beneficiaries and not the source of injustice, resentments in response to resentment, and resentments whose origin — in part — can be found in their very unintelligibility to us. Many social resentments focus on the personal costs of other people's needs, and the threat of a world in which the norms and values I take to be authoritative aren't taken seriously. Whether or not these resentments track claims that merit the attention of ethicists, policy makers, and activists is an open question: we must pay attention to social resentments in order to determine which do matter, both politically and ethically. But ultimately, my claim is that even so-called "unreasonable" resentments may contain morally significant messages of protest, even if those messages cannot yet express moral content. These messages are obscured if we stick too closely to the paradigm philosophy has thus far been prepared to offer.

I would like to thank Susanne Sreedhar, Amelie Rorty, Steven Burns, and Maren Behrensen as well as two anonymous referees, for their helpful comments and suggestions. Previous versions of this paper were presented to Philosophy Departments at the University of Western Ontario, Dalhousie University, Florida International University, and Boston University, as well as to the 2009 meeting of Feminist Ethics and Social Theory (FEAST). I am grateful for the critical attention of my audience in each case.

\section{Notes}

${ }^{1}$ There is cause for feminists to rejoice in this development. Feminists have long defended anger as an appropriate response to injustice, an act of insubordination, and a source of political insight and energy, even while "the reading of feminism as a form of anger allows the dismissal of feminist claims" (Ahmed 2004, 177). For a sample of feminist defenses of anger, see Frye 1983, Lorde 1984, Spelman 1996, Bell 2009.

${ }^{2}$ Of course, like most universal statements, Walker's has its exceptions: Justin D'Arms and Daniel Jacobson note that "resentment" in ordinary language is used to describe a kind of envy as well as a kind of anger (D'Arms and Jacobson 1993). Empirical psychological work on resentment also links it to envy (Feather and Sherman 2002).

${ }^{3}$ Philosophers do, however, take resentment to be an extremely common, perhaps universal, form of anger. Robert Solomon suggests something like this kind of anger is the best candidate we have for a "universal" emotion (Solomon 1993). Indeed, resentful anger may not even be limited to our 
species. In his extensive analysis of primate behavior, Frans de Waal records numerous rituals of what he calls "reciprocal retribution" or "moralistic aggression" among chimpanzees. Such rituals are often enacted to protect shared practices of food-gathering, valuable family relationships, or other alliances. From this and related studies of strategic peacemaking and reconciliation, de Waal concludes, we can assume our ancestors were guided by attitudes of "gratitude, obligation, retribution and indignation" long before we had the linguistic or cognitive capacity for moral discourse (De Waal 1989, 161).

${ }^{4}$ While the relationship between envy and resentment is not my focus in this paper, it is worth noting that the two appear more closely related than Rawls allows. As remarked in Note 1, D'Arms and Jacobson claim the term "resentment" can describe a species of moralized envy, as well as moralized anger (D'Arms and Jacobson 1993). Feather and Sherman remark that "feelings of resentment proper have more of a public, sanctioned character" (Feather and Sherman 2002, 953) and La Caze suggests that many forms of envy "relate to things that we believe others possess or have gained which they do not deserve," even if their undeserved success does not directly or indirectly harm the envier (La Caze 2001, 32).

${ }^{5}$ Murphy treats these three sources of value as interrelated and assumes that, in practice, an individual case of resentment will necessarily express all three. But it is not at all clear that every act that violates respect for persons in general necessarily entails disrespect to $m e$, in particular-and similarly with respect for moral values in general. A broader reading of resentment as expressing one of several interrelated forms of protest might allow us to treat these as criteria for distinguishing kinds of resentment.

${ }^{6}$ Nancy Potter says, "Resentment... [is] directed toward responsible wrongdoings" (Potter 2001, 137). Pamela Hieronymi argues that our resentment is sensitive to our judgments of responsible wrongdoing: "if we come to see they are unfounded, they will ... disappear" (Hieronymi 2001, 535). Richard Jay Wallace remarks that, in resenting, "we are demonstrating our commitment to certain moral standards" (Wallace 1994, 69). Thomas Brudholm also accepts this understanding, referring to resentment as an "accusing anger" (Brudholm 2008, 10).

${ }^{7}$ Marguerite La Caze notes that resentment is "generally considered to be [an] undesirable emotion which ought to be eliminated" (La Caze 2001, 31). Robert Solomon recognized its reputation as "the villain of the passions ... the most obsessive and enduring ... poisoning the whole of subjectivity with its venom" (Solomon 1993, 290).

${ }^{8}$ Wallace puts this point delicately, remarking that "resentment, it seems plain, is not necessarily a constructive sentiment" with "less happy manifestations" (Wallace 1994, 246).

${ }^{9}$ In fact, philosophical praise for resentment can be traced back beyond its post-Nietzschean rehabilitation, to eighteenth century British philosophy and-in particular-debates over the "naturalness" of justice. Hume, famously, conceived justice as an artificial virtue-although occasionally aided by natural feelings of resentment. But others (including Thomas Reid and Adam Smith) responded critically to Hume's proto-utilitarian account, and preferred Joseph Butler's writings on resentment (Harris forthcoming). For example, Smith locates our sense of justice in the passion of resentment, noting as he does that "resentment is commonly regarded as so odious a passion, that they will be apt to think it impossible that so laudable a principle, as the sense of ill desert of vice, should in any respect be founded upon it" (Smith 1976, II.i.5.7). Butler rescues resentment by linking it to what would otherwise be motivational deficiencies in our pursuit of retributive justice and our social deterrence of malice and wrongdoing. True, he concludes, there are some problems associated with resentment — namely, its tendency to self-perpetuate and escalate over time and its tendency to lead to abuse or excess - but these are only the result of partiality and self-love. To correct them, we need only curb our anger until we are "affected toward the injurious person in the same way any good man, interested in the case, would be..." (Butler 1949, 143). Resentment eventually collapses into indignation. All the elements of the modern account are present in Butler and Smith: in particularly, the direct perception of intentional wrongdoing, and the close association with legal justice, punishment-but equally, the desire for social harmony (MacLachlan 2010). 
${ }^{10}$ Not all philosophers who write on resentment would accept the terminology "moral sentiment," of course. Resentment re-emerges in contemporary moral philosophy in Peter Strawson's groundbreaking and influential discussion of participant reactive attitudes (Strawson 1993), attitudes central to how we make and acknowledge moral claims towards other people (Darwall 2006). Wallace acknowledges "it has been suggested that resentment (as distinct from ressentiment) is an inherently moral sentiment" but resists that conclusion himself (Wallace 1994, 248-49).

${ }^{11}$ Walker, one of the few people to offer a broad definition of resentment, gives an impressive list of resentments not provoked by personal moral injury: true, she acknowledges, we resent harms and losses, but some people also resent cheaters and free riders (even when we do not suffer as a result), those who engage in exploitation. We resent certain improprieties, as when someone gives themselves "airs" or authority to which we don't think they are entitled (again, even if we do not suffer), and-in contrast—we resent unjustified demotions or slights to our own status. Finally, Walker notes, resentment is often prompted by victimless cases of "rule-breaking, norm-violating, or simply behavior seen as 'out of bounds'": all seen as unacceptable offences (Walker 2006, 123-24). People can prickle, react, or seethe with resentment when provoked by any of these.

${ }^{12}$ Non-paradigmatic from the perspective of the philosophical paradigm, that is.

${ }^{13}$ Here I draw on the distinction between the ethical and the moral made by Bernard Williams, in his essay, "Morality, the Peculiar Institution." Williams describes morality as a particular system of ethical thinking, one distinguished by the "special notion of obligation it uses"-namely, one that takes the form of practical necessity (what I must do) (Williams 1985, 174). Williams' point is that morality is not the only way of thinking about ethical life and, moreover, adopting this approach to ethical life may lead one to strive for a kind of ethical purity, "abstracting the moral consciousness from other kinds of emotional reaction or social influence" (195). I am very much in sympathy with Williams's point, as it is exactly this desire for purity that leads philosopher to label resentments as either moral or political/social, instead of recognizing a more complex and overlapping relationship between the two.

${ }^{14}$ Political leaders in the most recent two North American federal elections committed what were arguably their biggest political gaffes when they waded into exactly these sorts of political resentments. President Barack Obama referred to his statement, "they get bitter, they cling to guns or religion or antipathy to people who aren't like them or anti-immigrant sentiment or anti-trade sentiment as a way to explain their frustrations," as "bone-headed" (Bai 2008). Canadian Prime Minister Stephen Harper lost the chance for a majority government in the furor that followed this claim: "I think when ordinary working people come home, turn on the TV and see a gala of a bunch of people at, you know, a rich [arts] gala all subsidized by taxpayers claiming their subsidies aren't high enough, when they know those subsidies have actually gone up-I'm not sure that's something that resonates with ordinary people." Harper thought he was tapping into national resentment toward the arts, and instead encountered Canadian anger in support of the arts, and resentment toward his distorted characterization of both artists (as rich) and Canadians (as uncouth) (CBC 2008).

${ }^{15}$ On June 8, 2008, Canadian Prime Minister Stephen Harper issued an apology on behalf of the Government of Canada to First Nations, Inuit and Métis former students and survivors of government and church-run residential schools. The residential school system operated in Canada until the end of the twentieth century, and was notoriously neglectful, cruel, and abusive. It was also the cornerstone of an explicitly racist government policy to "kill the Indian in the child." The apology and subsequent Truth and Reconciliation Commission are part of an enormous settlement package, mandated by the terms of a class action lawsuit on behalf of Indian residential schools survivors, in 2006 (Indian Residential Schools Settlement Agreement 2006).

${ }^{16}$ Wallace makes a similar distinction to Griswold, differentiating resentment from ressentiment (Wallace 1994, 246).

${ }^{17} \mathrm{Of}$ course, there is an irony here: for me to draw on them for examples of then-unrecognizable but ultimately compelling and resentment-worthy instances of injustice, it must be the case that we are now able to recognize them as the latter. But there are presumably as many instances of injustice 
not currently recognizable to the average philosophical reader of such. I think here of Martha Nussbaum's phrase: "frontiers of justice," and her point that the needs of people with disabilities, stateless persons and non-human animals are not accounted for within even some of the best philosophical theories of social justice (Nussbaum 2006).

\section{References}

Ahmed, Sara. 2004. The Cultural Politics of Emotion. New York: Routledge.

Allison, Dorothy. 1992. Bastard Out of Carolina. New York: Penguin.

1994. Skin: Talking about Sex, Class and Literature. New York: Firebrand Books.

Bai, Matt. 2008. Will Gun-Toting, Churchgoing White Guys Pull the Lever for Barack Obama? New York Times Magazine 2008. Retrieved April 12, 2009, from http://www.nytimes.com/2008/10/ 19/magazine/19obama-t.html?_r=4\&hp\&oref=slogin\&oref=slogin\&oref=slogin.

Bell, Macalester. 2009. "Anger, Oppression, and Virtue." In Feminist Ethics and Social and Political Philosophy: Theorizing the Non-Ideal, ed. Lisa Tessman, 165-83. New York: Springer.

Bennett, Christopher. 2002. "The Varieties of Retributive Experience.” The Philosophical Quarterly 52 (207): 145-63.

Brudholm, Thomas. 2008. Resentment's Virtue: Jean Améry and the Refusal to Forgive. Philadelphia: Temple University Press.

Butler, Joseph. 1949. Fifteen Sermons Preached at the Rolls Chapter and a Dissertation Upon the Nature of Virtue. Edited by W. R. Matthews. London: G. Bell and Sons Ltd.

Campbell, Sue. 1994. "Being Dismissed: The Politics of Emotional Expression." Hypatia 9 (3): 46-65.

CBC, Staff. 2008. Layton and Duceppe Protest Culture Cuts in Montreal. CBC News: Canada Votes 2008 2008. Retrieved April 12, 2009, from http://www.cbc.ca/news/canadavotes/story/2008/09/ 23/opposition-arts.html.

Crenshaw, Kimberly. 1989. "Demarginalizing the Intersection of Race and Sex: a Black Feminist Critique of Antidiscrimination Doctrine, Feminist Theory and Antiracist Politics." University of Chicago Legal Forum: 138-67.

D'Arms, Justin, and Daniel Jacobson. 1993. "The Significance of Recalcitrant Emotion (or, antiquasijudgmentalism." In Philosophy and the Emotions, ed. A. Hatzimoysis, 127-46. Cambridge: Cambridge University Press.

Darwall, Stephen. 2006. The Second Personal Standpoint: Morality, Respect and Accountability. Cambridge, MA: Harvard University Press.

De Waal, Franz. 1989. Peacemaking Among Primates. Cambridge, MA: Harvard University Press.

Dillon, Robin. 1997. "Self-Respect: Moral, Emotional, Political.” Ethics 107 (1): 226-49.

Feather, N. T., and Rebecca Sherman. 2002. "Envy, Resentment, Schadenfreude and Sympathy: Reactions to Deserved and Undeserved Achievement and Subsequent Failure." Personality and Social Psychology Bulletin 28 (7): 953-61.

Frye, Marilyn. 1983. “A Note on Anger.” In The Politics of Reality, 84-94. Berkeley, CA: Crossing Press.

Getz, Shay. 2008. Online Comment on Blog Entry: "For Many Aboriginal Children, Residential Schools were a Positive Experience." National Post Online 2008. Retrieved March 12, 2009, from http://network.nationalpost.com/np/blogs/fullcomment/archive/2008/5/30/rodney-a-cliftonfor-many-aboriginal-children-residential-schools-were-a-positive-experience.aspx.

Gilligan, Carol. 1990. "Joining the Resistance: Psychology, Politics, Girls, and Women." The Tanner Lectures on Human Values, from www.tannerlectures.utah.edu/lectures/documents/Gilligan_ 91.pdf.

Griswold, Charles L. 2007. Forgiveness: A Philosophical Exploration. Cambridge: Cambridge University Press.

Harris, James. Forthcoming. “The Early Reception of Hume's Theory of Justice.” In Philosophy and Religion in Enlightenment Britain, ed. Ruth Evelyn Savage. Oxford: Oxford University Press. 
Hieronymi, Pamela. 2001. "Articulating an Uncompromising Forgiveness." Philosophy and Phenomenological Research 62 (3): 529-55.

Indian Residential Schools Settlement Agreement. 2006. Retrieved March 17, 2009, from http:// www.residentialschoolsettlement.ca/settlement.html.

Jaggar, Alison. 2008. "Love and Knowledge: Emotion in Feminist Epistemology." In The Feminist Philosophy Reader, ed. Alison Bailey and Chris Cuomo, 687-704. New York: McGraw-Hill.

Kilpatrick, R., The Honourable Mr. Justice. 2006. Ammaq et al. v. Canada (Attorney General) NUCJ 24: Nunavut Court of Justice.

La Caze, Marguerite. 2001. "Envy and Resentment." Philosophical Explorations 1 (1): 31-45.

Lorde, Audre. 1984. "The Uses of Anger: Women Responding to Racism." In Sister Outsider, 124-33. Los Angeles: Crossing Press.

MacLachlan, Alice. 2010. "Resentment and Moral Judgment in Smith and Butler." Adam Smith Review 5: 161-77.

Murphy, Jeffrie G. 2003. Getting Even: Forgiveness and Its Limits. Oxford: Oxford University Press.

Murphy, Jeffrie G., and Jean Hampton. 1988. Forgiveness and Mercy. Cambridge: Cambridge University Press.

Nussbaum, Martha. 2006. Frontiers of Justice: Disability, Nationality, Species Membership. Cambridge, MA: Harvard University Press.

Potter, Nancy. 2001. "Is Refusing to Forgive a Vice?” In Feminists Doing Ethics, ed. Peggy DesAutels and Joan Waugh, 135-50. Lanham, MD: Rowman and Littlefield.

Rawls, John. 1987. A Theory of Justice. 2nd ed. Cambridge, MA: Harvard University Press.

Smiley, George. 2008. Online Comment on Blog Entry: "For Many Aboriginal Children, Residential Schools were a Positive Experience." National Post Online 2008. Retrieved April 12, 2009, from http://network.nationalpost.com/np/blogs/fullcomment/archive/2008/5/30/rodney-a-clifton-formany-aboriginal-children-residential-schools-were-a-positive-experience.aspx.

Smith, Adam. 1976. A Theory of Moral Sentiments, ed. D. D. Raphael and A. L. Macfie. Indianapolis, IN: Liberty Fund.

Solomon, Robert. 1993. The Passions: Emotions and the Meaning of Life. Indianapolis, IN: Hackett.

Spelman, Elizabeth. 1996. “Anger and Insubordination.” In Women, Knowledge and Reality: Explorations in Feminist Philosophy, ed. Ann Garry and Marylin Pearsall, 263-74. New York: Routledge.

Strawson, Peter. 1993. "Freedom and Resentment." In Perspectives on Moral Responsibility, ed. John Martin Fischer and Mark Ravizza, 45-66. Ithaca, NY: Cornell University Press.

Tessman, Lisa. 2005. "The Burdened Virtues of Political Resistance." In Feminist Interventions in Ethics and Politics, ed. Barbara Andrew, Jean Keller and Lisa Schwartzman, 77-96. Lanham, MD: Rowman \& Littlefield.

Walker, Margaret Urban. 2006. Moral Repair: Reconstructing Moral Relations after Wrongdoing. Cambridge: Cambridge University Press.

Wallace, R. Jay. 1994. Responsibility and the Moral Sentiments. Cambridge, MA: Harvard University Press.

Williams, Bernard. 1985. "Morality, the Peculiar Institution." In Ethics and the Limits of Philosophy, 174-96. London: Fontana. 